The Impact of Tourism in

East Africa 


\section{TOURISM AND CULTURAL CHANGE}

Series Editors: Professor Mike Robinson, Ironbridge International Institute for Cultural Heritage, University of Birmingham, UK and Professor Alison Phipps, University of Glasgow, Scotland, UK

Understanding tourism's relationships with culture(s) and vice versa is of ever-increasing significance in a globalising world. TCC is a series of books that critically examine the complex and ever-changing relationship between tourism and culture(s). The series focuses on the ways that places, peoples, pasts and ways of life are increasingly shaped/transformed/ created/packaged for touristic purposes. The series examines the ways tourism utilises/makes and re-makes cultural capital in its various guises (visual and performing arts, crafts, festivals, built heritage, cuisine, etc.) and the multifarious political, economic, social and ethical issues that are raised as a consequence. Theoretical explorations, research-informed analyses and detailed historical reviews from a variety of disciplinary perspectives are invited to consider such relationships.

All books in this series are externally peer-reviewed.

Full details of all the books in this series and of all our other publications can be found on http://www.channelviewpublications.com, or by writing to Channel View Publications, St Nicholas House, 31-34 High Street, Bristol BS1 2AW, UK. 


\title{
The Impact of Tourism in East Africa
}

\author{
A Ruinous System
}

\section{Anne Storch and Angelika Mietzner}




\section{DOI https://doi.org/10.21832/STORCH8373}

Library of Congress Cataloging in Publication Data

A catalog record for this book is available from the Library of Congress.

Names: Storch, Anne, author. | Mietzner, Angelika, author.

Title: The Impact of Tourism in East Africa: A Ruinous System/Anne Storch and Angelika Mietzner. Description: Blue Ridge Summit: Channel View Publications, 2021. | Series:

Tourism and Cultural Change: 58 | Includes bibliographical references and index. | Summary: "This book explores the relationship between imperial formations and individual encounters at African tourist sites. It examines how encounters between tourists and hosts tend to be constructed along colonial thought lines and shows that ruination is omnipresent in postcolonial tourist settings. This book is open access under a CC BY ND licence" - Provided by publisher.

Identifiers: LCCN 2020056466 (print) | LCCN 2020056467 (ebook) |

ISBN 9781845418366 (paperback) | ISBN 9781845418373 (hardback) |

ISBN 9781845418380 (pdf) | ISBN 9781845418397 (epub) | ISBN 9781845418403 (kindle edition) Subjects: LCSH: Tourism-Social aspects-Africa, East. | Language and culture-Africa, East. | Sociolinguistics-Africa, East.

Classification: LCC G156.5.S63 S76 2021 (print) | LCC G156.5.S63 (ebook) |

DDC 306.48190967-dc23 LC record available at https://lccn.loc.gov/2020056466

LC ebook record available at https://lccn.loc.gov/2020056467

British Library Cataloguing in Publication Data

A catalogue entry for this book is available from the British Library.

ISBN-13: 978-1-84541-837-3 (hbk)

ISBN-13: 978-1-84541-836-6 (pbk)

ISBN-13: 978-1-84541-838-0 (pdf)

ISBN-13: 978-1-84541-839-7 (epub)

\section{Open Access}

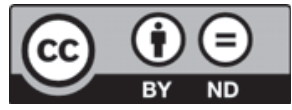

Except where otherwise noted, this work is licensed under the Creative Commons Attribution-NoDerivatives 4.0 International License. To view a copy of this license, visit http:/creativecommons.org/licenses/ by-nd/4.0/ or send a letter to Creative Commons, PO Box 1866, Mountain View, CA 94042, USA.

\section{Channel View Publications}

UK: St Nicholas House, 31-34 High Street, Bristol BS1 2AW, UK.

USA: NBN, Blue Ridge Summit, PA, USA.

Website: www.channelviewpublications.com

Twitter: Channel_View

Facebook: https://www.facebook.com/channelviewpublications

Blog: www.channelviewpublications.wordpress.com

Copyright (C) 2021 Anne Storch and Angelika Mietzner.

All rights reserved. No part of this work may be reproduced in any form or by any means without permission in writing from the publisher.

The policy of Multilingual Matters/Channel View Publications is to use papers that are natural, renewable and recyclable products, made from wood grown in sustainable forests. In the manufacturing process of our books, and to further support our policy, preference is given to printers that have FSC and PEFC Chain of Custody certification. The FSC and/or PEFC logos will appear on those books where full certification has been granted to the printer concerned.

Typeset by Nova Techset Private Limited, Bengaluru and Chennai, India.

Printed and bound in the UK by the CPI Books Group.

Printed and bound in the US by NBN. 